\title{
Urban Tree Species Identification and Carbon Stock Mapping for Urban Green Planning and Management
}

\author{
Md Abdul Mueed Choudhury ${ }^{1, *}$, Ernesto Marcheggiani ${ }^{1,2, * \mathbb{C}}$, Francesca Despini ${ }^{3}$, \\ Sofia Costanzini ${ }^{3}\left(\mathbb{D}\right.$, Paolo Rossi ${ }^{3}\left(\mathbb{D}\right.$, Andrea Galli ${ }^{1}$ and Sergio Teggi ${ }^{3} \mathbb{D}$ \\ 1 Department of Agricultural, Food and Environmental Sciences, Marche Polytechnic University, \\ 60131 Ancona, Italy; a.galli@staff.univpm.it \\ 2 Division of Forest, Nature and Landscape, Department of Earth and Environmental Sciences, KU Leuven, \\ 3001 Leuven, Belgium \\ 3 Department of Engineering Enzo Ferrari, University of Modena and Reggio Emilia, 41125 Modena, Italy; \\ francesca.despini@unimore.it (F.D.); sofia.costanzini@unimore.it (S.C.); paolo.rossi@unimore.it (P.R.); \\ sergio.teggi@unimore.it (S.T.) \\ * Correspondence: m.choudhury@pm.univpm.it (M.A.M.C.); e.marcheggiani@staff.univpm.it (E.M.)
}

Received: 3 November 2020; Accepted: 20 November 2020; Published: 21 November 2020

\begin{abstract}
Recently, the severe intensification of atmospheric carbon has highlighted the importance of urban tree contributions in atmospheric carbon mitigations in city areas considering sustainable urban green planning and management systems. Explicit and timely information on urban trees and their roles in the atmospheric Carbon Stock (CS) are essential for policymakers to take immediate actions to ameliorate the effects of deforestation and their worsening outcomes. In this study, a detailed methodology for urban tree CS calibration and mapping was developed for the small urban area of Sassuolo in Italy. For dominant tree species classification, a remote sensing approach was applied, utilizing a high-resolution WV3 image. Five dominant species were identified and classified by applying the Object-Based Image Analysis (OBIA) approach with an overall accuracy of $78 \%$. The CS calibration was done by utilizing an allometric model based on the field data of tree dendrometry-i.e., Height $(\mathrm{H})$ and Diameter at Breast Height (DBH). For geometric measurements, a terrestrial photogrammetric approach known as Structure-from-Motion (SfM) was utilized. Out of 22 randomly selected sample plots of 100 square meters $(10 \mathrm{~m} \times 10 \mathrm{~m})$ each, seven plots were utilized to validate the results of the CS calibration and mapping. In this study, CS mapping was done in an efficient and convenient way, highlighting higher CS and lower CS zones while recognizing the dominant tree species contributions. This study will help city planners initiate CS mapping and predict the possible CS for larger urban regions to ensure a sustainable urban green management system.
\end{abstract}

Keywords: urban trees; OBIA classification; SfM approach; allometric model; carbon stock mapping; city planners

\section{Introduction}

In recent decades, ceaseless urbanization and intensifying global warming have led to increased levels of atmospheric carbon in urban areas. For city planners and researchers, understanding the contribution of trees in mitigating atmospheric carbon in urban areas has become one of the paramount concerns. The planning and management of urban parks and trees to decelerate the worsening impacts of severe carbon emissions have been explored in many different studies [1-7]. For instance, empirical research found that the mean aboveground urban tree carbon stock (dry biomass) across the Seattle urbanizing region was $89 \pm 22 \mathrm{Mg} \mathrm{C} / \mathrm{ha}$, which is a significant quantity considering the severe atmospheric carbon in city areas $[8,9]$. Thus, there is now a growing need to study urban green 
infrastructures and characterize tree species in response to Carbon Storage (CS) variations and their future impacts. Moreover, it is essential to identify the dominant species and their CS potential to ensure environmental equity associated with the resulting ecological benefits [10-12]. Traditionally, information and studies on urban tree structures have used random field sampling and visual interpretation via aerial photos, which are generally expensive, labour-intensive, and time-consuming processes and are typically unable to cover a larger area of interest [12-15]. Nevertheless, research on urban tree features, such as their identification, classification, and CS mapping, faces challenges due to the use of non-uniform and multifunctional approaches and a lack of relevant information [12,16].

Recently, Remote Sensing (RS), improved with its latest features (i.e., hyperspectral imagery and high spatial resolution satellite imagery) being introduced as efficient observational and analytical tools, ensuring a robust and easily adaptable means to analyse and identify characteristic vegetation information. Moreover, remote sensing approaches coupled with GIS (Geographic Information Systems) are very useful tools to investigate large areas with reduced time and cost. Tree features, such as their structures (i.e., Height (H), biomass, leaf area, and stems), contributions (i.e., ecological benefits), and arrangements (species abundance and variability) have been identified, classified, and mapped by successfully utilizing remote sensing tools [12,17-22]. Satellite remote sensing has been widely used for tree species identification and classification over the last few decades [23-30]. Even in the case of urban trees, high spatial resolution satellite imagery has been utilised to identify the species along with the individual tree crown extraction [31-41]. However, the classification of urban tree canopy types and species utilizing high spatial resolution satellite imagery faces challenges in urban areas due to their higher urban surface cover heterogeneity, frequent shaded areas of trees and buildings, and the complexity of urban forests compared to natural and planted forests [24,42-46]. Considering these facts, it is increasingly necessary to engage in frequent investigations exploring the potential of high spatial resolution satellite imagery for urban tree classification and species mapping. In this study, an RS approach was used to determine the best possible ways to classify urban trees using remote sensing data combined with ground truth measurements. High-resolution WorldView 3 (WV3) image data were considered in this analysis, providing eight multispectral bands in the visible and Near-Infrared (NIR) regions, which is far better than the traditional four-band IKONOS and QuickBird data used for vegetation analyses [47]. As multispectral image data processing has become increasingly difficult, most studies recommend the application of the Object-Based Image Analysis (OBIA) approach to improve the classification accuracy in urban areas [48-52]. The OBIA approach was also implemented in this study to classify and identify the dominant tree species for further CS mapping.

For CS estimations, based on tree allometry, the information on tree dendrometry, such as tree Height $(\mathrm{H})$ and Diameter at Breast Height $(\mathrm{DBH})$, was collected during field measurements. Lidar and 3D reconstruction techniques are often applied in vegetation investigations [53-58] to measure the main geometries of trees-in particular, the tree Height $(\mathrm{H})$ [59]. In this study, a terrestrial photogrammetric approach was applied to produce accurate point clouds of urban trees. Terrestrial photogrammetry, such as small UAV photogrammetry, can be quickly implemented in urban areas for the detection of a small portion of trees or a single tree because of the wide diffusion of these instruments. Modern photogrammetry provides the advantages of the Structure-from-Motion (SfM) algorithm, which permits 3D reconstruction from a series of high-redundancy images acquired without any rigorous design $[53,60]$. A ground topographic survey is still required, however, to provide correct scaling or georeferencing to generate 3D models. SfM using dense image matching algorithms is a new technique, yet few studies apply this method to tree measurements, especially using linear metrics, such as the DBH, H, crown spread, and the stem radius [55-57,59,61]. When performing geometric characterizations, an evaluation of the obtained accuracies is required to validate successive analyses. In this study, the applied SfM approach was validated with traditional methodologies to estimate the accuracies in geometric parameter estimation [62]. 
This study was conducted in the northern part of Italy focusing on the small city area of Sassuolo, which is also known as one of the most severely polluted urban areas in Europe. An allometric model [63] developed specifically for the trees in Italy was utilised for the CS calibration. Five dominant species were identified covering the whole study area, and the CS/plot was calibrated and mapped based on each species.

Herein, the main goal was to understand the potential of this methodology in mapping the tree CS in an urban area considering the role of dominant urban tree species in atmospheric carbon mitigation. This method might be an efficient tool to assist urban planners in CS mapping to ensure the proper utilisation of the available green space. Thus, this study highlights that accurate tree CS mapping is crucial for estimating and identifying the dominant species contributing a significant level of atmospheric CS, which will prove to be useful support for urban planners and environmental policymakers in planning further urban air quality assessments. This study will contribute to a better understanding of this methodology in mapping structural and functional properties, such as tree CS, as well as predicting the possible urban CS in typical city areas.

\section{Materials and Methods}

\subsection{Data Set}

The study area is the city of Sassuolo, province of Modena, located in the Po Valley in the northern part of Italy (Figure 1). The Po valley experiences strong anthropic pressure due to its large urban areas, intensive agriculture (among the most productive agricultural areas within Europe), and large manufacturing districts, along with topographic and meteorological conditions unfavourable to pollutant dispersion [64-66].

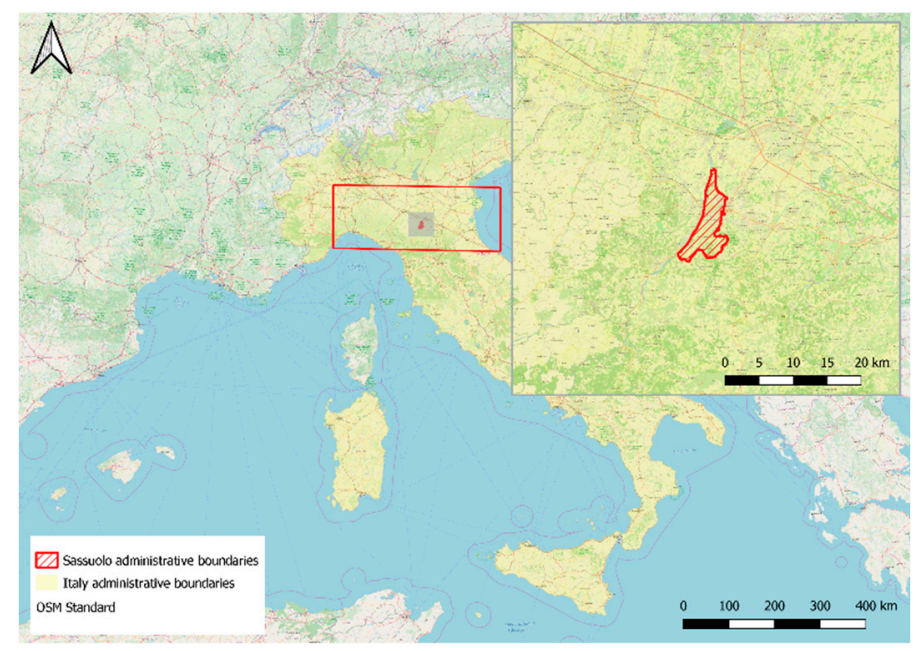

Figure 1. The location of the study area in Sassuolo, Italy.

The total investigation area is an urban area of around 273 ha (Figure 1). Five dominant tree species (Quercus spp., Acer campestre, Populus nigra, Platanus spp., and Tilia platyphyllos) were identified, covering all the main streets and parks.

The key data for this study were WorldView 3(WV3) images, shapefiles available from the Geoportal of the Emilia Romagna Region [67], and data collected from the sample plots. Shapefiles were extracted from the CORINE Land Cover (CLC) map [68], a database of land use in the territory. In this study, artificial surfaces were extracted from the map, such as streets and public green areas. The WV3 image data for this study were acquired on 31 July 2018 (Figure 2). The WV3 includes one panchromatic band with a $0.3 \mathrm{~m}$ resolution and eight multispectral bands with a $1.2 \mathrm{~m}$ resolution (Table 1). 


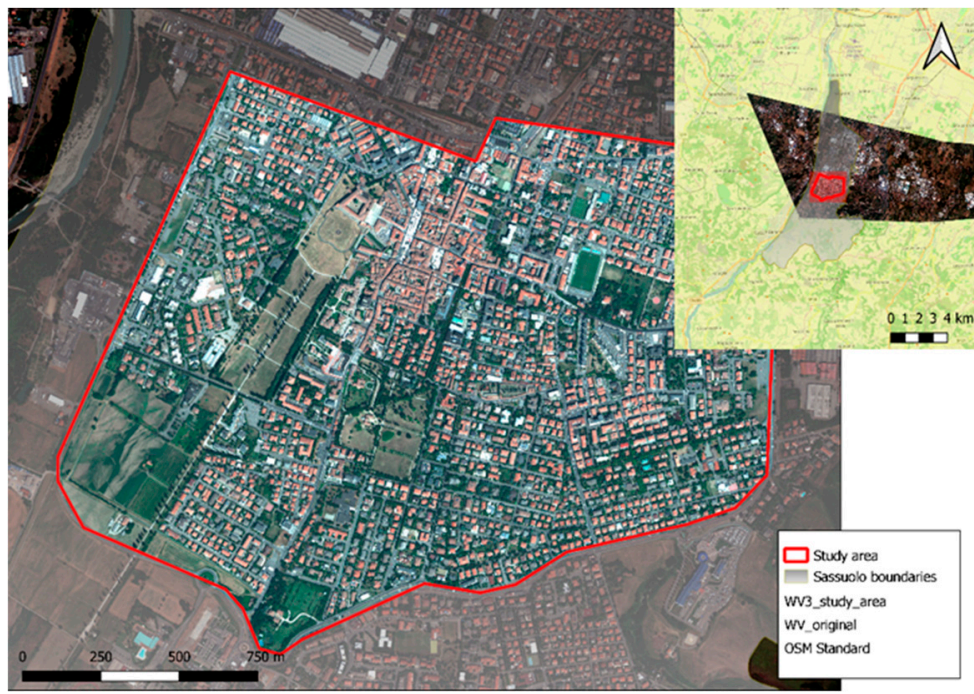

Figure 2. The WV3 image data: the original image and the study area in Sassuolo.

Table 1. Eight multispectral bands along with their wavelengths in the WV3 image.

\begin{tabular}{cc}
\hline Bands & Wavelength (nm) \\
\hline Coastal band & $400-450$ \\
Blue band & $450-510$ \\
Green band & $510-580$ \\
Yellow band & $585-625$ \\
Red band & $630-690$ \\
Red edge band & $705-715$ \\
Near Infrared (NIR)1 band & $770-895$ \\
Near Infrared (NIR)2 band & $860-1040$ \\
\hline
\end{tabular}

The image also includes eight SWIR bands with a spatial resolution of $7.5 \mathrm{~m}$. As this spatial resolution is not very suitable for tree species classification, these bands were not considered in this study. However, the additional four bands—i.e., coastal, yellow, red-edge and NIR2—did provide some significant advantages for vegetation identification and classification [47,69].

\section{Data Collection}

For the field data collection, 22 plots of $100 \mathrm{~m}^{2}(10 \mathrm{~m} \times 10 \mathrm{~m})$ each (Figure 3) were randomly selected considering the dominant tree species covering the whole study area of Sassuolo. Among them, seven plots were considered for the CS mapping and validation. The fundamental considerations were to measure the $\mathrm{DBH}$ and $\mathrm{H}$ of each tree, along with each tree's geographical coordinates, and to determine the names of the species. $\mathrm{DBH}$ measurements were done at $1.3 \mathrm{~m}$ above ground level. To obtain the $\mathrm{H}$ of the trees, a photogrammetric approach was applied. For this purpose, $2 \mathrm{D}$ pictures were taken at each plot utilizing a handheld digital camera while considering 3D model development through the SfM photogrammetric approach [23]. Several pictures were acquired from different positions, thereby differentiating between short and tall trees. Field data $(\mathrm{H}, \mathrm{DBH})$ were collected in October 2018 and were essential for the CS calibration. The sample plots were also used during the training and validation of the tree species classification. The time gap between the acquisition dates of the WV3 images (July) and the field data collection (October) did not affect the identification of the different species and their classification. Indeed, 3D reconstruction of the trees to calculate their $\mathrm{H}$ is more important when there are only a few leaves (better vision of the tops of the trees). Moreover, for tree species classification, the image from July was especially convenient, as the CS computation (In QGIS; Section 2.2.4) was based on the NDVI, which is strictly correlated with tree biomass. 


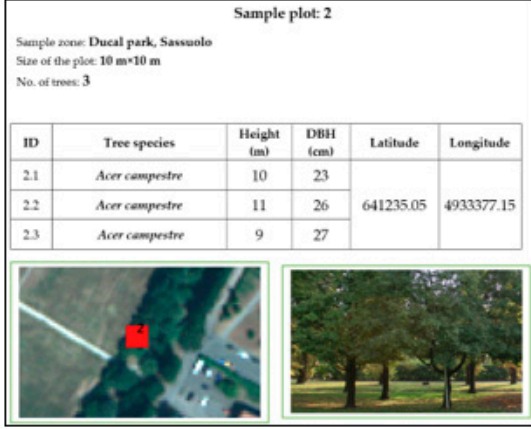

(a)

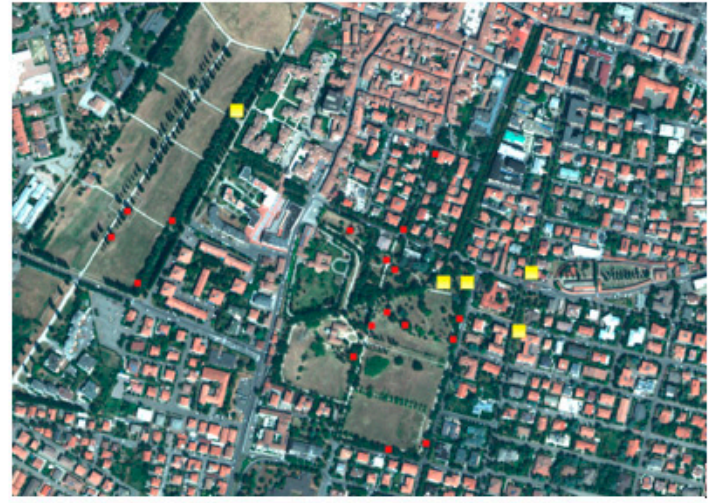

(b)

Figure 3. (a) One of the data sheets showing the plot position (Red square) and trees (Left) along with the required data; (b) sample plots (Red squares) with the validation plots (Yellow squares).

\subsection{Methodology}

\subsubsection{Pre-Processing}

In the first stage, the WV3 multispectral image was processed to convert Digital Numbers into the Top of Atmosphere (TOA) radiance. Then atmospheric corrections were performed using the FLAASH plugin of the Environment for Visualizing Images (ENVI) software [70]. In this way, it was possible to retrieve the Surface Reflectance (SR). Then, some of the required features-i.e., the Normalized Difference Vegetation Index (NDVI), the Grey Level Co-occurrence Matrix (GLCM), and the Principal Component Analysis (PCA) for OBIA classification [47]—were computed.

NDVI is a very common vegetation index used in several remote sensing studies [71]. For evaluating a vegetative area, the equation for calculation of the NDVI is as follows:

$$
N D V I=\frac{\rho_{N I R}-\rho_{R E D}}{\rho_{N I R}+\rho_{R E D}}
$$

where

$\rho_{\text {NIR }}=$ reflectance in the near-infrared band;

$\rho_{R E D}=$ reflectance in the red band .

For this work, several NDVI calculations were performed using both the NIR1 and NIR2 Near Infrared bands along with the red edge band.

GLCM is a tabulation of the frequency of different combinations of grey levels at a specified distance and orientation in an image object [72]. For principal component analysis, only the first and second principal components were used. In this way, it was possible to retrieve the less-correlated information from the original eight multispectral bands [73].

\subsubsection{Object Based Classification}

In urban areas, the traditional pixel-based image classification method usually provides low classification accuracy due to the high spectral variability within the land cover classes affected by the sun angle, gaps in the tree canopies, and shadows [74,75]. Indeed, urban tree classification with higher accuracy is still a considerable challenge, and most studies recommend the application of the Object Based Image Analysis (OBIA) approach to improve classification accuracy in urban areas [49-52]. Herein, the OBIA approach was also applied to improve classification accuracy [49-52,76]. The OBIA method includes not only spectral information but also other added information, such as context, texture, geometry, and spatial features [36,77], which can minimise the number of units to be considered for the classification [78]. Segmentation is the key procedure used to divide an image into different 
significant objects in which the spectral and spatial features will be computed. The segmentation procedure divides the image into spatially continuous and homogeneous regions [79] and limits local spectral variation $[49,50]$. For this study, the Trimble eCognition Developer ${ }^{\circledR} 9$ platform (Trimble, Munich, Germany) [80] was utilised for the OBIA approach.

In this study, both segmentation and classification were implemented in successive steps to obtain the best results. At first, a chessboard segmentation was carried out using the shapefiles of the Municipality of Sassuolo extracted from the Corine Land Cover (CLC) map of the Emilia-Romagna Region. In particular, the shapefiles of streets and public green areas (i.e., parks) were utilized.

Green areas and streets were identified with very large objects (used as the sizes of the shapefile polygons) and classified separately from the other objects. In these areas, subsequent multiresolution segmentation was applied to the smaller objects. For this segmentation, instead of thematic layers, the spectral information and geometric information of the WV3 bands were considered. After that, based on the study of Li et al. [47], the spectral and textural features (NDVIs, GLCM, and PCA) were included to obtain better results in classification. A total of 79 features were added to the eight bands of the image.

The result after the second segmentation was a series of smaller objects with a good degree of homogeneity among themselves. The resulting medium-sized objects were suitable for the study of tree crowns. The parameters used for segmentation, after numerous tests, were determined as follows: scale parameter $=10$, shape $=0.2$, and compactness $=0.5$.

By using the threshold values for some of the features such as the Brightness and NDVI, the initial classes such as shadows, pathways and grass were identified. Then, relying on the sample plots, several ground-truth samples (ROIs, Regions of Interest) were chosen for the different tree species. Dominant species were identified distinctly for parks and roads. This was done to obtain classification with better accuracy, as the tree species diversity in parks is usually higher than that on the streets. In the case of parks, the main classes were identified as follows:

- Acer campestre;

- Populus nigra;

- Platanus spp.;

- Quercus spp.

In the case of streets, the main classes were identified as follows:

- Platanus spp.;

- Quercus spp.;

- Tilia platyphyllos.

The sample plots were used for the classification algorithm training, where the chosen method used the Nearest Neighbour (NN) algorithm [81].

After the training step, the NN algorithm was implemented for the assignment of objects to the different classes. Features like the mean and the standard deviation for all bands, the average values of the different NDVI indexes, the Grey level Co-occurrence Matrix, and the Principal Components were included in the feature space [59]. In this study, these features were chosen to provide improved classification under the OBIA approach. For instance, the NN algorithm was used separately for trees in the parks and on the streets. This algorithm was applied to select the different dominant species and thereby obtain more accurate tree species classification. Thus, in the classification map, the suffix -street or -park was used even for the same tree species (see the "Results" section). In this way, the accuracy of the classification was improved because the sampling points were chosen separately for parks and streets. Once the classification was done, other samples were used for the validation phase. In this way, it was possible to calculate the accuracy of the proposed methodology in this area. 


\subsubsection{Photogrammetric Approach}

For the tree $\mathrm{H}$ measurement, the SfM photogrammetry approach was introduced (Figure 4). This approach usually allows for the 3D reconstructions of objects through the acquisition of 2D images for estimating the required features [23]. In this study, a 3D model was developed for each plot to measure the individual tree $\mathrm{H}$ to calibrate the CS via the allometric model [63]. The Agisoft Metashape (AM) software was utilized to produce 3D models applying the SfM algorithm [23,59,82]. In each plot, all the trees were photographed from different directions to ensure maximum data redundancy and the best accuracies. The images were captured with a handheld digital SLR camera from photo-points at regular intervals around the perimeter of each plot. A semi-circular pathway around each plot from the inner to outer part of the plot was followed to capture each image successively, thereby covering all the trees (Figure 5). Images were acquired with different camera inclinations to avoid occlusions. About 120-150 photos/plot were taken depending on the sizes of the trees.

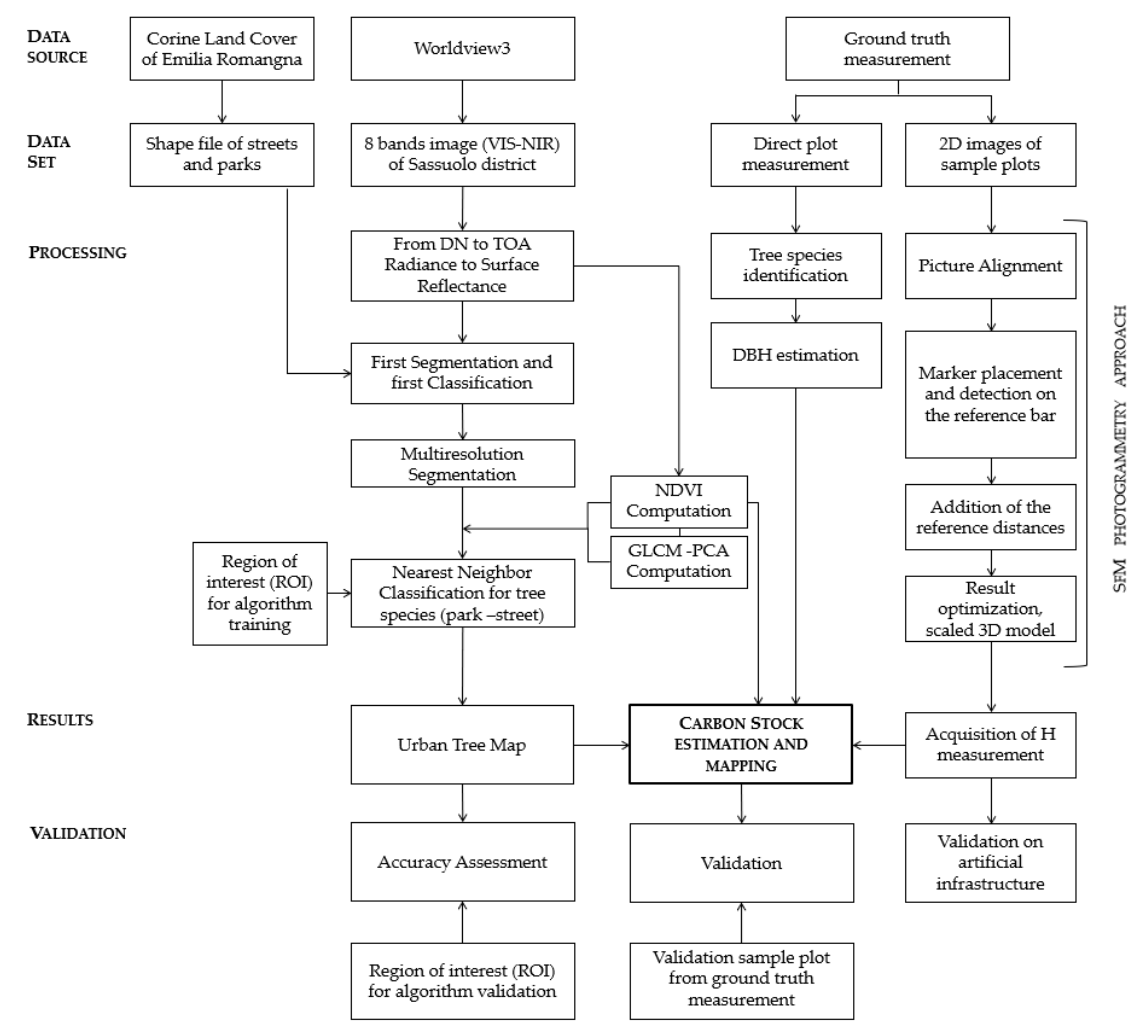

Figure 4. The flowchart of the overall methodology for Carbon Stock (CS) mapping considering the dominant tree species in Sassuolo.

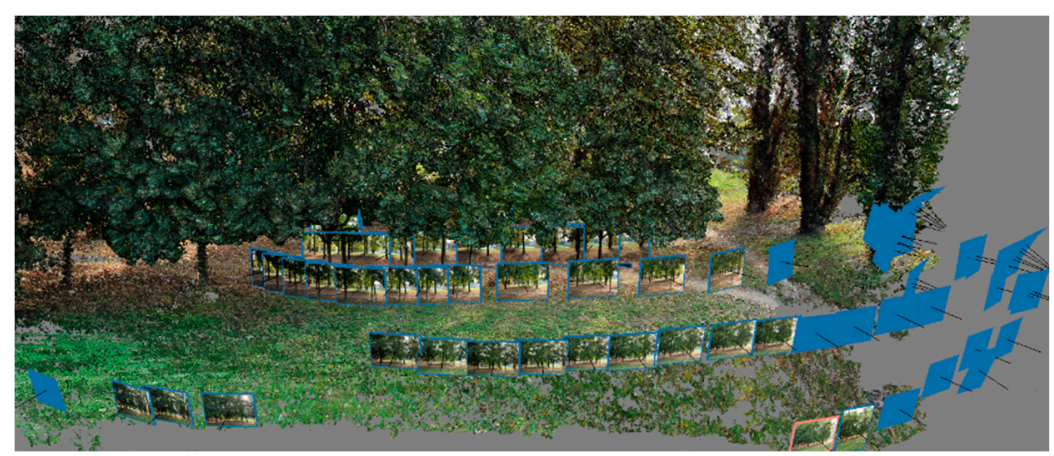

Figure 5. Dense point clouds of one of the investigated plots (AM model view); the blue squares represent the locations of the acquired images. 
The inner circle photos were taken from a distance to include the tree-top, middle, and bottom parts of the tree, and the outer photos were oriented to include the whole tree within the frame. This approach ensured a high redundancy of images (each portion of the area of interest must be detected to have 9-10 images at least) [23]. Moreover, a varying view of the geometry must be guaranteed to obtain accurate results. If no information about the camera position or points with known coordinates are added to the project, the reconstructed 3D point cloud will be generated within an arbitrary reference system lacking georeferencing and scale.

In this case study, to obtain a 3D scaled point cloud and measure the tree $\mathrm{H}$ in the 3D model, a $4 \mathrm{~m}$ graduated bar (Figure 6) was added to the area of interest as a reference and depicted in various images. As the positioning of an object with known dimensions is an external constraint used for reconstruction that allows the generation of scaled products, the applied methodology is feasible for the measurement purposes of this study [83]. Tree H estimation was done by performing measurements on the reconstructed $3 \mathrm{D}$ model.

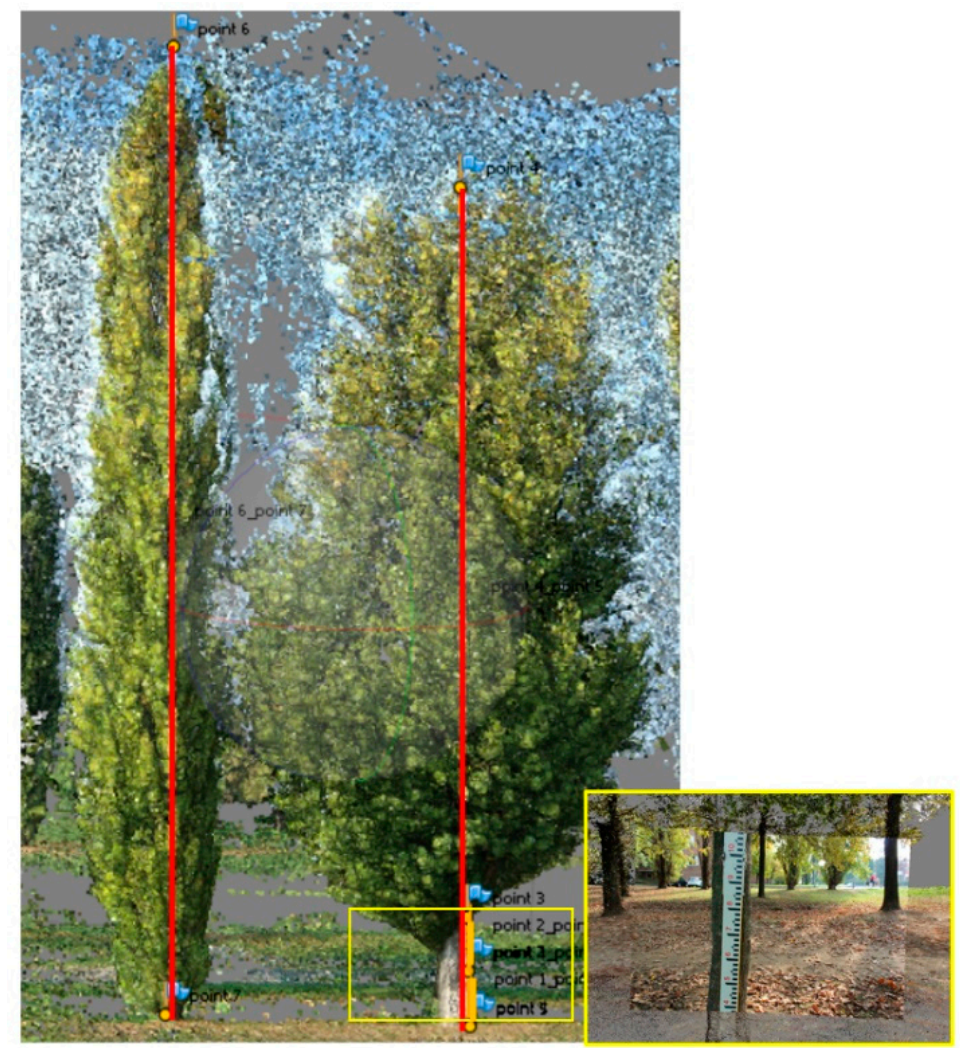

Figure 6. Three-dimensional model of sample plot 4 . The blue flags are the added markers, and the yellow lines (on right-side tree's lower trunk) are the segments on the reference bar (the yellow box shows the reference bar) used to constrain the reconstruction, while the red lines are the segments created for $\mathrm{H}$ estimation.

The AM software was used to generate the 3D model for each plot, and in each model, the reference scale bar was visible enough to constrain the reconstruction (Figure 6). From the 3D model, H estimation was done using the scale creation tool available in the AM software. Once the markers were placed on some of the aligned images, the corresponding 3D marker was automatically added to the 3D model. Then, the lengths of the segments among the points of interest were determined. The identified lengths provided the estimated tree H utilizing the SfM approach.

Validation of the results was mandatory to assess the metric accuracy of the performed measurements. The photogrammetric SfM approach was thus compared via laser scanning. A Leica C10 scan station was used for this purpose, and the resolution and accuracy of the resulting point 
clouds were about a few $\mathrm{mm}(<5 \mathrm{~mm})$ in size. Laser scanning and photogrammetry were independent technological methodologies used for 3D model generation.

The results obtained with the proposed photogrammetric methodology were compared with those of the laser scanning technique to validate the results and guarantee the metric accuracy of the $\mathrm{H}$ measurements. The reconstruction of a small portion of a building was performed using both technologies. The validation area was chosen to provide better identification of homologous points. A direct comparison of the generated point clouds was not suitable for this study, so the lengths of various segments were verified (Figure 7 and Table 2) to enable a proper investigation of the accuracy of the applied methodology. During the $\mathrm{H}$ estimation, the errors were measured while considering the estimated values in both cases. The identified differences in the two datasets were about $4 \mathrm{~cm}$; if the longer segments (the ones exceeding $10 \mathrm{~cm}$ ) are taken into consideration, the difference is $6 \mathrm{~cm}$.

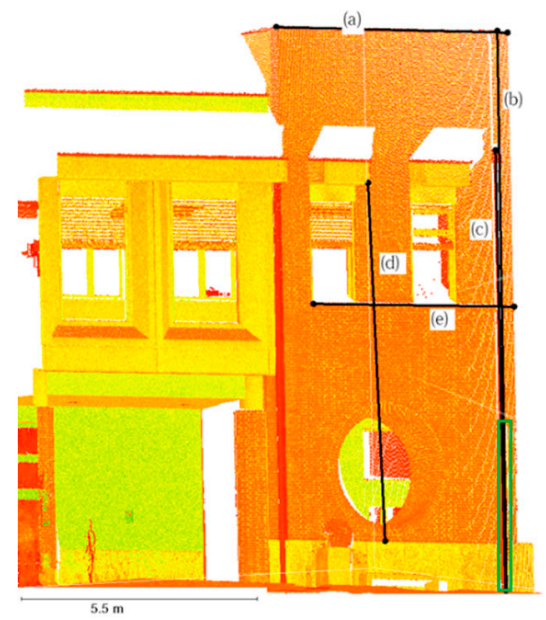

Figure 7. Laser scanning 3D point cloud of the test area including the segments (a-e). Green portion: The reference scale bar used to constrain the photogrammetric model; black lines: Distances used for validation.

Table 2. The results obtained during metric validation of the obtained 3D models.

\begin{tabular}{cccc}
\hline Segment & Laser Scanning & Photogrammetry & Discrepancy \\
\hline (a) & $6.19 \mathrm{~m}$ & $6.21 \mathrm{~m}$ & $0.02 \mathrm{~m}$ \\
(b) & $13.21 \mathrm{~m}$ & $13.16 \mathrm{~m}$ & $0.05 \mathrm{~m}$ \\
(c) & $10.38 \mathrm{~m}$ & $10.45 \mathrm{~m}$ & $0.07 \mathrm{~m}$ \\
(d) & $8.35 \mathrm{~m}$ & $8.38 \mathrm{~m}$ & $0.03 \mathrm{~m}$ \\
(e) & $5.38 \mathrm{~m}$ & $5.41 \mathrm{~m}$ & $0.03 \mathrm{~m}$ \\
\hline \multicolumn{5}{c}{} \\
\hline
\end{tabular}

\subsubsection{CS Mapping in QGIS}

During CS mapping in QGIS, the shapefile of the classified trees was utilized to determine the $\mathrm{CS} /$ plot for each identified species. First, the total Above Ground Biomass (AGB) was calculated considering the field data (i.e., the $\mathrm{DBH}, \mathrm{H}$, tree species, etc.) for each of the sample plots (Figure 4). For this calculation, an allometric model [63] was applied to calculate the AGB for each plot. The mean $\mathrm{AGB} /$ plot estimation was necessary, as it is recommended that the tree above ground CS be $50 \%$ of the total AGB [84-88]. Then, to estimate the mean CS/plot, the mean AGB/plot was multiplied by 0.5 as a conversion factor [89-91]. Next, in QGIS, the NDVI (Utilizing red edge and NIR1 bands) of the whole study area was computed utilizing the WV3 image data. The NDVI layer was considered in this study for CS predictions and mapping, as several studies claimed to find a strong correlation between the NDVI and total AGB of the trees [92-95]. The NDVI-derived metrics were extracted for the sample plots utilizing the "Zonal statistics" plugin [96] in the QGIS interface. After that, linear 
regression models were created in a Microsoft ${ }^{\circledR}$ Excel ${ }^{\mathrm{TM}}$ spreadsheet considering the mean CS/plot and the NDVI-derived metrics to determine the best model to estimate and map CS covering the whole study area. A fishnet of a $100 \mathrm{~m}^{2}(10 \mathrm{~m} \times 10 \mathrm{~m})$ resolution was built in QGIS to recognize the minimum to maximum CS zones based on the dominant species classification shapefile obtained from the WV3 image data. The classification shapefile was essential to define the required zones that provided QGIS data to map the estimated CS values considering only the dominant tree species. Otherwise, the map would show the CS values for other areas-e.g., the areas covered with grass or even areas with no vegetation.

\section{Results}

\subsection{OBIA Classification Results and Validation}

In this study, the OBIA approach was applied based on the spectral and textural attributes of the image objects for generating rule sets during classification. Although it was challenging to detect some of the classes due to their spectral similarities, 4 species in the parks and 3 species in the streets were found to be dominant in Sassuolo (Figure 8).

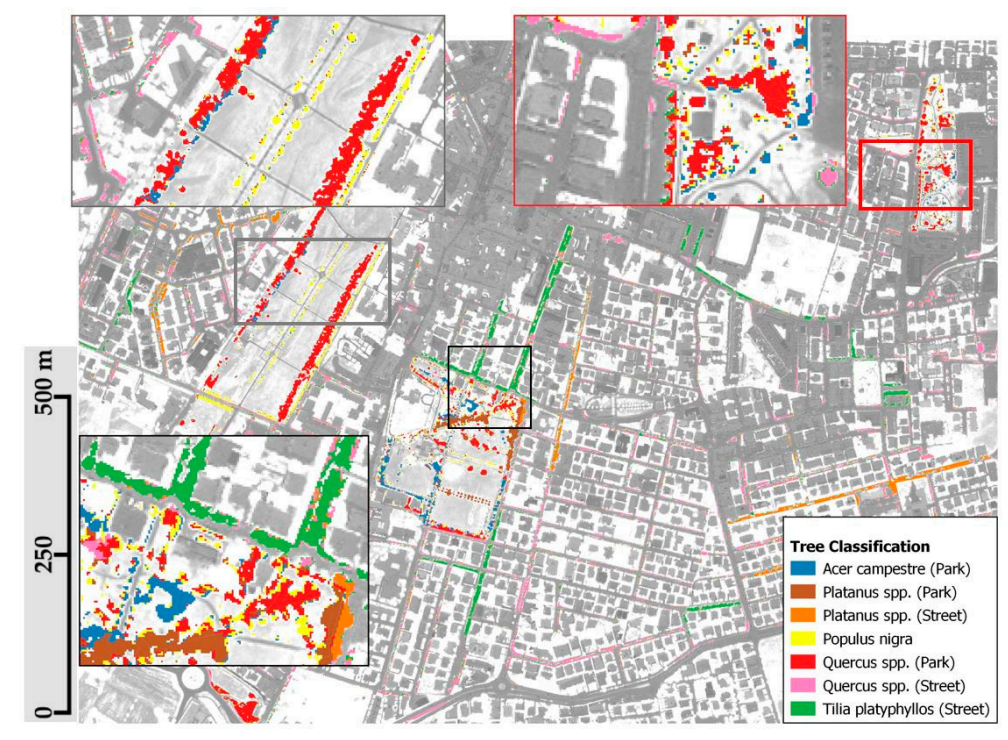

Figure 8. The overall classification obtained with the OBIA approach utilizing WV3 data for the study area in Sassuolo.

The classification validation was done through the confusion matrix [97-99], which allows one to determine the overall accuracy of the classification in addition to some parameters related to user and producer accuracy. The presence of validation is necessary to define the effectiveness of the classification and determine the error percentage.

Validation was carried out only for tree species that were representative of the classes of interest. The areas for validation were chosen with a percentage equal to $5 \%$ of the total area for the tree species based on the sample plots and a deep knowledge of the territory. The validation results are shown in Table 3.

The producer accuracy indicates the completeness of classification, while the user accuracy indicates the classification's correctness [100]. The Hellden parameter represents the mean accuracy of individual classes. The mean accuracy for class $i$ is calculated using the equation presented in [101]:

$$
\text { Mean accuracy }(i)=\frac{2 A}{B+C} 100 \%
$$


where $A$ is the number of correctly classified reference points for class $i, B$ is the total number of reference points in class $i$ in the reference data, and $C$ is the total number of reference points classified into class $i$ [102].

KIA is the well-known Kappa Index of Agreement (or Cohen's kappa coefficient), which measures the proportion of agreement after chance agreements have been removed from consideration. The kappa increases to one as the chance agreement decreases and becomes negative the less often that chance agreement occurs [103].

The overall accuracy is the ratio of the sum of diagonal values of the confusion matrix to the total number of cell-counts in the matrix. This value gives an idea of the accuracy for all the considered classes [104].

Table 3. Validation results expressed in percentages.

\begin{tabular}{|c|c|c|c|c|c|c|c|}
\hline & $\begin{array}{c}\text { Populus } \\
\text { nigra }\end{array}$ & $\begin{array}{c}\text { Quercus } \\
\text { spp. } \\
\text { Park }\end{array}$ & $\begin{array}{c}\text { Acer } \\
\text { campestre } \\
\text { Park }\end{array}$ & $\begin{array}{c}\text { Tilia } \\
\text { platyphyllos } \\
\text { Street }\end{array}$ & $\begin{array}{c}\text { Platanus } \\
\text { spp. } \\
\text { Park }\end{array}$ & $\begin{array}{c}\text { Quercus } \\
\text { spp. } \\
\text { Street }\end{array}$ & $\begin{array}{c}\text { Platanus } \\
\text { spp. } \\
\text { Street }\end{array}$ \\
\hline $\mathrm{PA}^{1}$ & 0.87 & 0.79 & 0.68 & 0.63 & 0.81 & 0.70 & 0.82 \\
\hline $\mathrm{UA}^{1}$ & 0.79 & 0.89 & 0.81 & 0.52 & 0.73 & 0.55 & 0.97 \\
\hline Hellden & 0.83 & 0.83 & 0.74 & 0.57 & 0.77 & 0.62 & 0.89 \\
\hline $\begin{array}{l}\text { KIA per } \\
\text { Class }\end{array}$ & 0.83 & 0.71 & 0.65 & 0.59 & 0.78 & 0.68 & 0.79 \\
\hline & & \multirow{2}{*}{\multicolumn{2}{|c|}{ Overall Accuracy }} & \multicolumn{2}{|c|}{0.78} & & \\
\hline & & & & \multicolumn{2}{|c|}{0.74} & & \\
\hline
\end{tabular}

${ }^{1}$ PA: Producer Accuracy, UA: User Accuracy.

\subsection{SfM Approach for H Estimation}

The results showed that the average $\mathrm{H}$ was very significant for each of the species (Table 4). The average discrepancies between the photogrammetric and laser scanning estimated lengths were in the order of a few centimetres, which proved the applicability of the SfM approach for tree H estimation. In most cases, marker placement on the treetop was largely responsible for the increased average error. For instance, for taller trees-e.g., Populus nigra-the estimated mean $\mathrm{H}$ was $29.15 \mathrm{~m}$, with an average error of 0.3 to $0.4 \mathrm{~cm}$. In other cases, the average errors were lower, except for the overlapping treetops. Unfortunately, there are few studies on urban tree $\mathrm{H}$ estimation utilising SfM approaches with AM software, so the general European Forest Tree (EFT) database published in 2016 [105] was considered for this study to provide a possible comparison. Even though this database was released for forestry areas, comparing the results with this database was still interesting. For instance, for the tree species such as Acer campestre, Quercus spp., and Populus nigra, the estimated average heights were $10.14,16.15$, and $29.15 \mathrm{~m}$, respectively (Table 4). However, according to the EFT database, the average height for Acer campestre is typically $15 \mathrm{~m}$ and 30 and $40 \mathrm{~m}$, respectively, for Quercus spp. and Populus nigra [106-108]. Other recent studies also estimated the average $\mathrm{H}$ at $18.83 \mathrm{~m}$ for Quercus spp., and, for the Populus nigra, the $\mathrm{H}$ was determined as $23 \pm 5 \mathrm{~m}$ in Spain and Sweden $[109,110]$. The differences between the $\mathrm{H}$ values of the trees in this study and the $\mathrm{H}$ values in the other studies are possibly due to the following reasons:

- These other studies were done in forestry areas under different environmental conditions;

- In urban areas, the sizes and shapes of the tree crowns are modified at regular intervals;

- In this study, most of the trees were located in the streets, where frequent tree growth does not occur. 
Table 4. Estimated (SfM approach) mean H values of the dominant species in all the sample plots.

\begin{tabular}{cc}
\hline Tree Species & Mean Height (m) \\
\hline Quercus spp. & 16.15 \\
Acer campestre & 10.14 \\
Populus nigra & 29.15 \\
Platanus spp. & 18.2 \\
Tilia platyphyllos & 12.52 \\
\hline
\end{tabular}

\subsection{Urban CS Mapping and Validation}

The CS for the dominant species was calculated and mapped in QGIS showing the intensity of CS based on the species in different zones (Figure 9). Figure 9 shows that the CS map estimated based on the classification shapefile was relevant for all the identified dominant species. For the trees that were not shaded or overlapped by the other dominant species, the computed NDVI and CS mapping was significant.

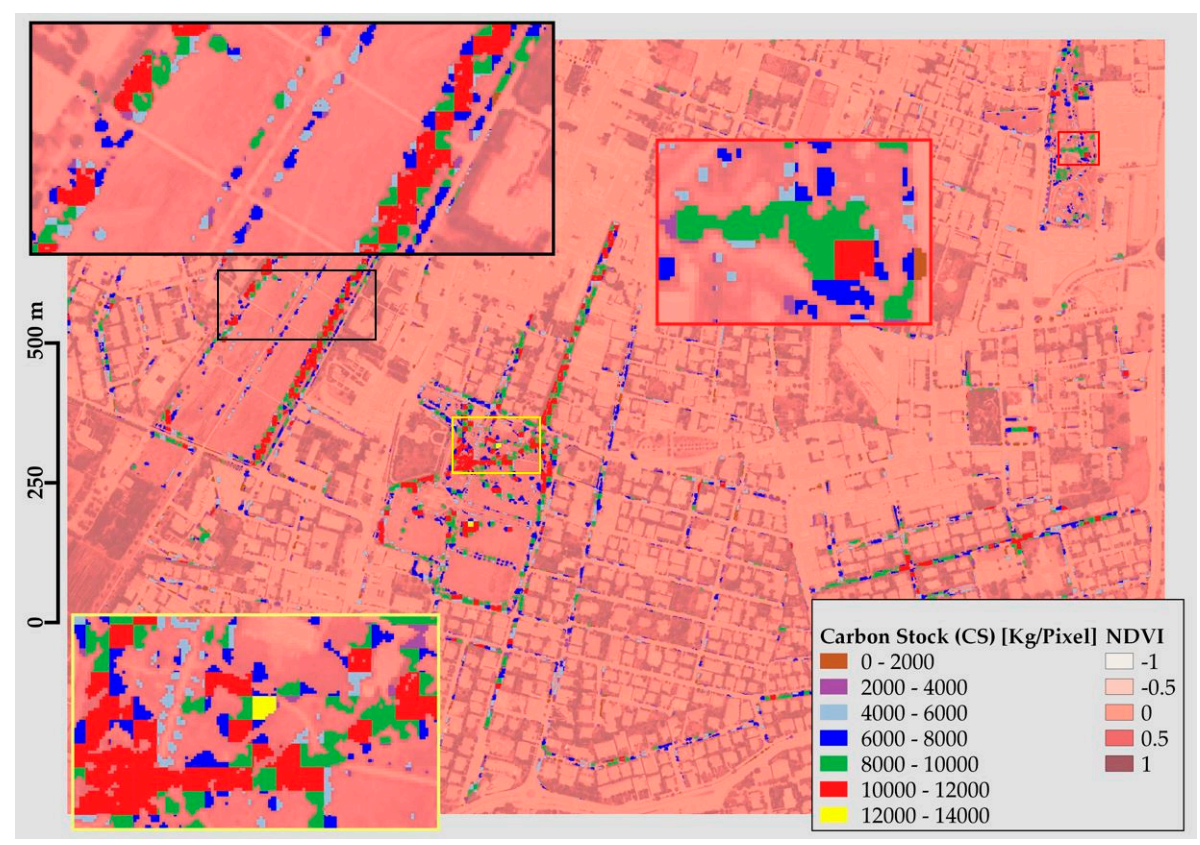

Figure 9. The estimated (QGIS) CS based on different dominant species and their distributions.

Among the five dominant species, the species Quercus spp., Tilia platyphyllos, and Platanus spp. were found to be most responsible for the atmospheric CS covering the areas with higher CS intensity (Red, green, and brown zones at TC in Figure 10). Only in the case of Populus nigra (the blue and pink zones at CS in Figure 10) did the values indicate moderate to low CS zones.

The outcome of the CS mapping for the dominant species proved the reliability of the applied methodology, even for complex urban areas (Figure 11). Figure 11 shows the outcome of CS mapping for the dominant species in the whole urban area represented as a box plot graph. Generally, higher values (see the median values for each species) were found for the species Acer campestre, Platanus spp., Populus nigra, and Quercus spp. in the parks. Maximum values were generally found for Acer campestre (park) and Platanus spp. (street), while lower values were found for Quercus spp. (street), as in previous studies [111]. 


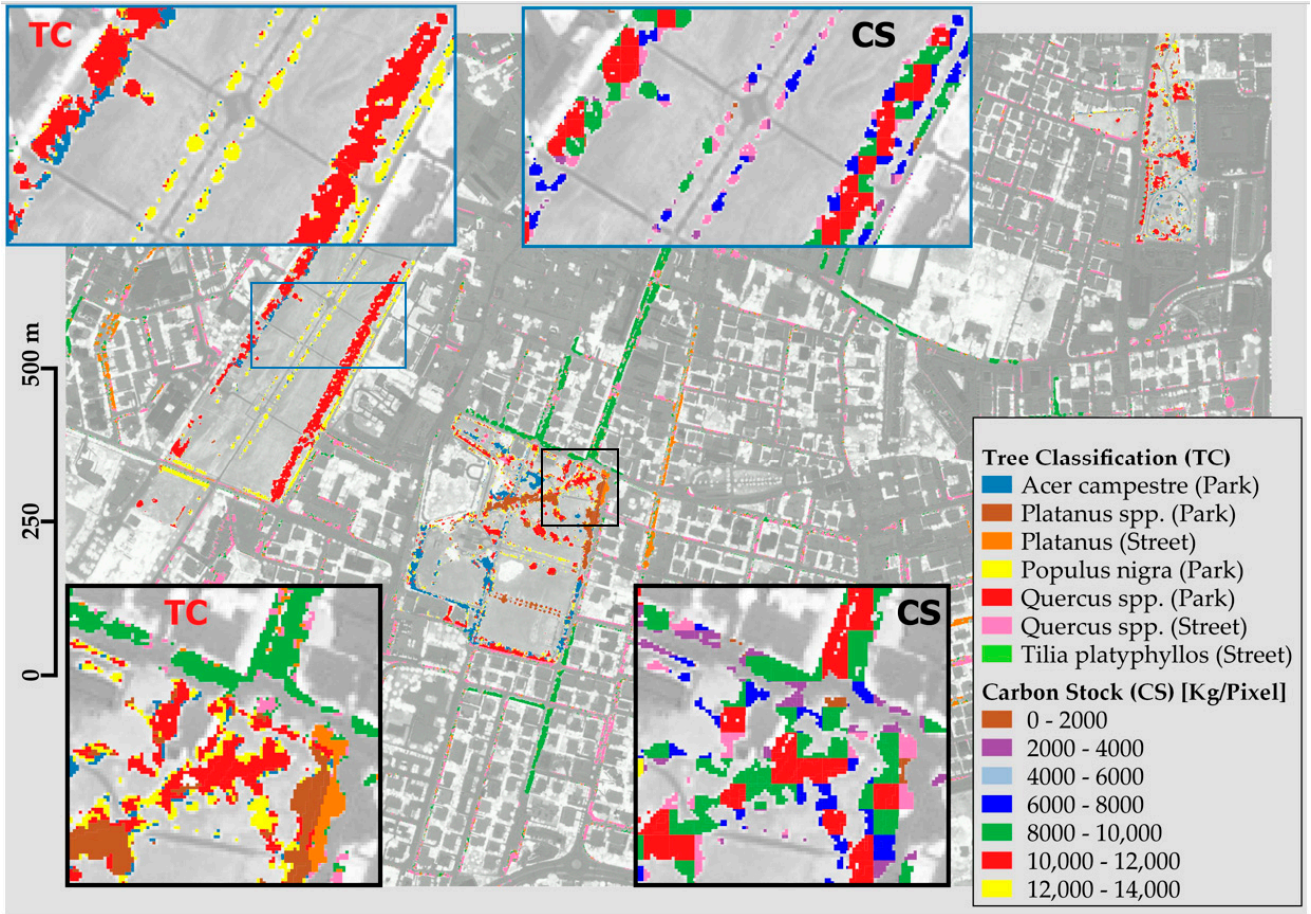

Figure 10. Comparison of the estimated CS (QGIS) for the dominant species in the parks and streets.

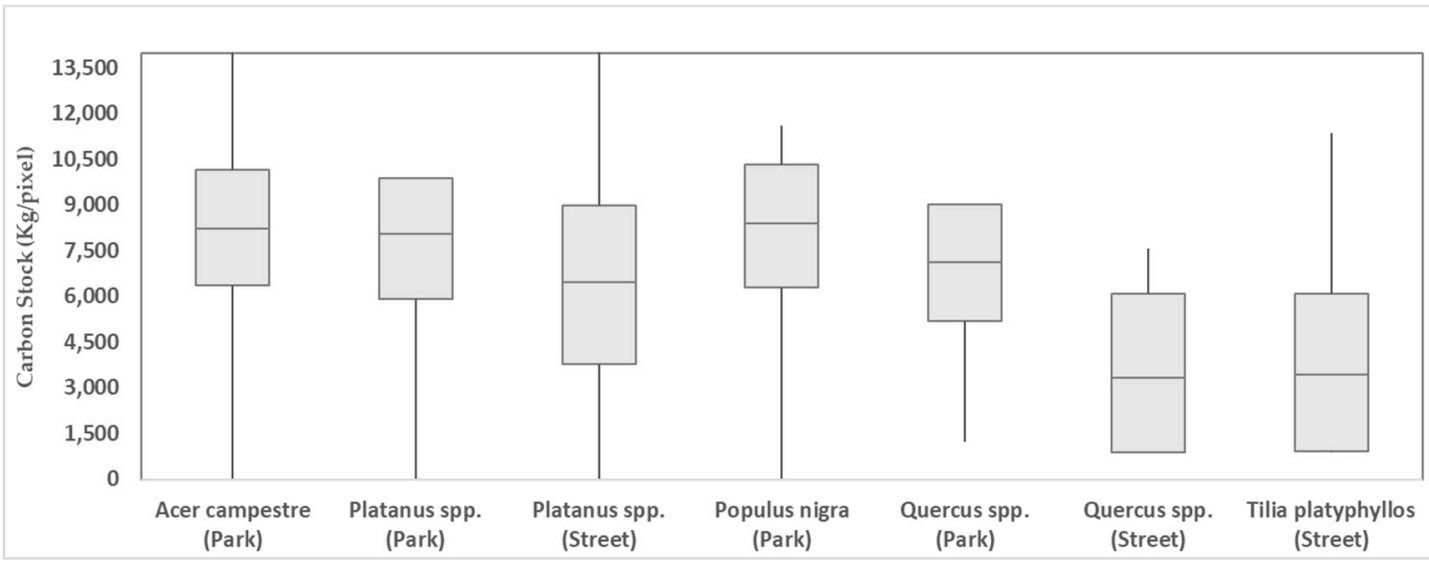

Figure 11. The overall results of the computed CS mapping in QGIS for all the dominant species.

For the CS mapping validation, seven randomly selected plots were considered. Considering all the dominant species, four plots from the streets and another three plots were selected from the parks. The results show that the CS estimations in all cases had a smaller difference with the QGIS-computed CS values, except for plots 5 and 7, which showed higher differences in their estimations (Table 5). The NDVI-based QGIS computations were found to be more applicable for street trees, which were more evident in the WV3 image than the park trees. Smaller species found in parks (i.e., Acer campestre) showed higher CS values and were overlapped by the other dominant species. On the other hand, Populus nigra, a taller tree species, presented lower CS values and was also found to be an isolated species with higher CS values during the field estimations.

A regression analysis was also performed to determine the CS computational efficiency during the mapping. In the case of the street trees, the coefficient of determination was greater than $80 \%$ $\left(\mathrm{R}^{2}=0.85\right)$, and the overall $\mathrm{R}^{2}$ value was 0.42 when considering all the validation plots, except for the plot with "Populus nigra" (Figure 12). The Populus nigra showed a large difference in CS estimations because of its typical fastigiate structure and status as a true "Lombardy poplar" with a very narrow 
crown [112]. Due to its narrow crown, this species was not as evident and provided a lower NDVI value, leading to a lower computation of CS. However, in other cases, the park tree species (e.g., Acer campestre) were mixed and adjacent to the other dominant species and had significantly higher computed NDVI values. Due to being surrounded by other larger crowns, the small-structured species presented higher NDVI values, which is why Acer campestre also showed a larger difference in the CS estimation, as Acer campestre is a shorter tree species than the others. On the other hand, the species on the streets (i.e., Platanus spp. and Tilia platyphyllos), were found to be isolated and planted with adequate spacing. They were also more evident in the WV3 image, showing smaller differences in CS estimations (Table 5). As the validation plots were selected at random, only two plots out of the seven plots yielded lower $\mathrm{R}^{2}$ values, which was true only for those plots because, for the overall CS computation, both species (Acer campestre and Populus nigra) were found to be efficient in atmospheric CS like all the other dominant species (Figure 11). Thus, the proposed methodology is more efficient $\left(R^{2}=0.85\right)$ for dominant urban tree species (Figure 11), except for those with overlapping/narrow-crowned $\left(R^{2}=0.42\right)$ structures in a complex urban environment (Figure 12).

Table 5. The results obtained during the validation of the estimated CS in the validation plots.

\begin{tabular}{ccccc}
\hline Plot ID & Tree Species & $\begin{array}{c}\text { Mean } \\
\text { CS/plot (Kg) }\end{array}$ & $\begin{array}{c}\text { CS/plot (Kg) } \\
\text { Computed in QGIS }\end{array}$ & $\begin{array}{c}\text { Estimation } \\
\text { Differences (kg)/plot }\end{array}$ \\
\hline $\mathbf{1}$ & Platanus spp. (Street) & 124 & 180 & 55 \\
$\mathbf{2}$ & Platanus spp. (Street) & 105 & 207 & 102 \\
$\mathbf{3}$ & Platanus spp. (Street) & 655 & 453 & 202 \\
$\mathbf{4}$ & Tilia platyphyllos (Street) & 262 & 361 & 99 \\
$\mathbf{5}$ & Acer campestre (Park) & 51 & 375 & 324 \\
$\mathbf{6}$ & Quercus spp. (Park) & 226 & 374 & 148 \\
$\mathbf{7}$ & Populus nigra (Park) & 817 & 289 & 528 \\
\hline
\end{tabular}

\section{Correlation between the} field and QGIS estimation in streets.

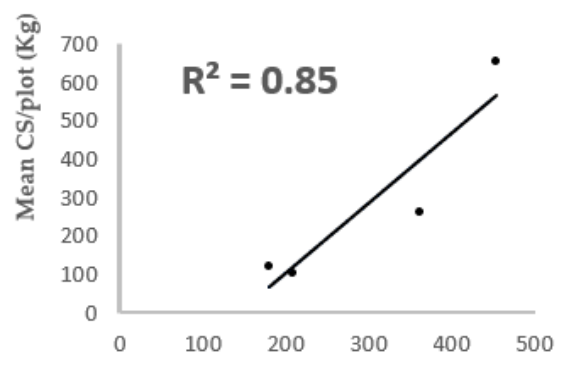

(a)

Estimated CS/plot in QGIS (Kg)

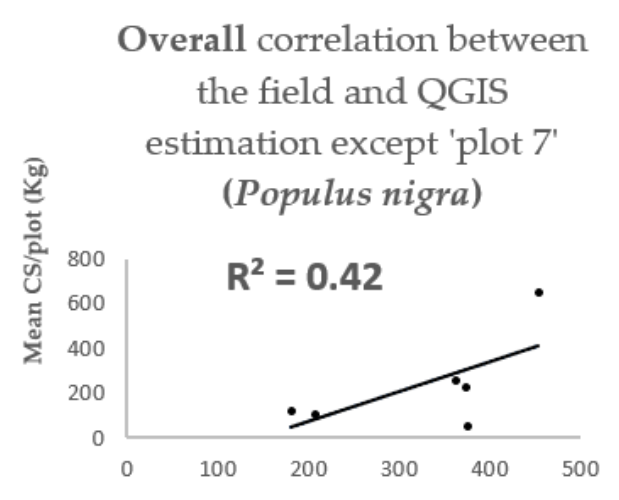

(b) Estimated Cs/plot in QGIS (Kg)

Figure 12. Linear correlation between field estimations and QGIS computations of the CS/plots (a) for species on the streets and (b) among all the trees except for 'Populus nigra' at the validation plots.

\section{Discussion}

The OBIA approach applied in this study was found to be an efficient approach for tree species classification. The overall accuracy of the thematic mapping was $78 \%$, with a kappa index of 0.74 . For the different classes of species, the accuracy level varied from high (89\% for the Platanus spp.) to low (57\% for the Tilia platyphyllos). Usually, the selection of training samples for use with the $\mathrm{NN}$ algorithm had a significant influence on the accuracy of the classification [113]. The quantity of the selected samples must be adequate to allow the algorithm to distinguish the various classes. This is why we chose to distinguish between park trees and street trees. Ad hoc samples were chosen for the dominant species for both streets and parks. Then, two separate classifications were 
performed. In this way, the algorithm was able to show the best outcomes in both areas with higher accuracy. The spectral characteristics of the different species of trees highlighted some common traits of spectral responses that were too difficult to differentiate. That is why classification features such as NDVI, PCA, and GLCM were included in the feature space to obtain a classification with better results [47]. Consequently, the classification accuracy was almost $80 \%$, which was also able to satisfy the requirements for this study.

The use of remote sensing techniques for urban tree species mapping ensures significant time savings compared to the traditional species mapping of the territory $[114,115]$. To increase classification performance, images acquired at different time periods could be used to exploit the distinction between evergreen and non-evergreen plants.

In the case of the urban areas, such as Sassuolo, as in all Italian cities, there are numerous species of trees, historic gardens, and vegetation of various types. The OBIA approach was able to distinguish trees from other types of vegetation, but differentiating between many diverse species was not be possible. The common spectral characteristics of many species will make it more difficult to produce classification with higher accuracy. It is, therefore, imperative to identify dominant species to reduce errors in classification and to effectively focus on the tree species with higher density in the area.

The SfM methodology is efficient and feasible, especially for urban tree metrics, such as dendrometry [53,59]. The applied instruments, moreover, are consumer-grade and easy to use. The graduated bar ensures the real dimensions of the detected object with minimal effort on the field. Field operations are also simple and convenient and do not require any special skills for execution. The generated model is not georeferenced but was also found to be applicable for the estimation of dendrometry in tree CS calibration.

The results obtained from the applied methodology were validated for cases with similar settings. The laser scanning technique was used as a reference for validation, as this technique provides a direct method for 3D reconstruction, allowing direct measurements of each point's position. The choice of an anthropic object for validation of the proposed SfM approach facilitated identification of the homologous segments to enable comparison between the two methodologies (Table 2). This analysis revealed discrepancies of about $4 \mathrm{~cm}$, which means that the accuracy of the applied SfM approach is in the order of a few centimeters, which is suitable for the purposes of the proposed investigations. However, the quality of the 3D reconstruction could be improved by using small UAVs (Unmanned Aerial Vehicles) during the acquisition of images.

The methodology implied in this study will have significant impacts on CS calculations [116] and mapping for the dominant species in city areas. The mapping results in this study show that the species that are most evident (i.e., located on the streets), and not shaded or overlapping, have more significant CS values based on the field estimations. The application of remote sensing for dominant tree species identification made this methodology more convenient in terms of time investment and expenses than traditional tree identification (Figure 11). The proposed methodology will not only provide an efficient way to understand the contributions of different species in atmospheric CS but will also provide other significant information, such as the following:

- An estimation of the total benefits of individual dominant tree species considering the total predicted carbon sequestration;

- Understanding the consequences of ensuring adequate plant spacing when planning urban green areas;

- Identifying the most efficient dominant species based on their roles in urban ecology to better utilize the available urban space.

However, further studies should be done with more sample plots for field sampling and validation. CS mapping largely depends on the accuracy of tree classification, which could be challenging in densely vegetated urban areas. This is why the present study only considered the dominant species. This study was performed to understand the perspectives and opportunities of the applied methodology. 
It would be interesting to determine the CS mapping efficiency in larger city areas with a vast quantity of diverse tree species.

However, proper understanding of the urban tree species contributions in atmospheric carbon sequestration and storage remains one the most pertinent issues for urban green planning and management $[117,118]$. A convenient mapping method is a prerequisite not only for tree CS prediction but also to understand the roles of the dominant tree species to improve the urban environment while considering other ecological benefits. The CS mapping considered in this study could also be used for larger city areas where it remains a significant challenge to develop a map without visiting and marking each tree manually. This is why the mapping efforts utilized here provide a more efficient way to implement proper urban green management and tree plantation systems to provide an improved urban atmosphere for city dwellers.

\section{Conclusions}

While CS mapping remains time-consuming and entangled with the traditional tree by tree method, this study provides a strong baseline from which to proceed with tree species classification and CS mapping in urban areas. This study will be helpful for future studies of applied approaches like SfM for geometric parameter estimation and the OBIA classification approach. For instance, WV3 images with eight bands (i.e., the coastal band, yellow band, red edge, and NIR2 band) are far better for dominant species classification in urban areas than traditional four-band images (usually using the blue band, green band, red band, and NIR band). For estimations of the accuracy level, urban tree species classification outcomes largely depend on the positions, crown structures, and spectral attributes of the trees. In this study, tree species classification was obtained with an overall accuracy value of $78 \%$. The distinction between the park and street trees, moreover, improved classification accuracy. Furthermore, the CS map reveals that the tree stand levels and species distribution might have a significant influence on the total atmospheric CS for each species in urban areas. Aside from a few cases, the proposed methodology would provide an adequate solution for the efficient CS mapping of dominant urban tree species. This study was designed to assess and explore the feasibility of the proposed CS mapping approach in a typical urban area to demonstrate this method's efficient application compared to traditional approaches. The present method will help researchers and city planners implement advanced methods of CS mapping for typical urban areas to ameliorate the unavoidable impacts of climate change. This study, however, is not conclusive. This approach will next be implemented in a larger city area. Indeed, an experiment is currently underway in the capital city of Belgium that will compare its results with those of another approach (LiDAR data-derived CS mapping outcomes) to develop a method that is more convenient and less resource-intensive in all cases. That will enhance the feasibility of the approach even in the case of a significantly different context, such as in the case of a larger Asian metropolis.

Author Contributions: Conceptualization, A.G., E.M. and M.A.M.C.; methodology, M.A.M.C.; data curation, M.A.M.C. and F.D.; writing—original draft preparation, M.A.M.C., E.M., F.D., S.C. and P.R.; writing-review and editing, M.A.M.C., E.M., F.D., S.C. and P.R.; supervision, A.G., E.M. and S.T. All authors have read and agreed to the published version of the manuscript.

Funding: This research received no external funding.

Conflicts of Interest: The authors declare no conflict of interest.

\section{References}

1. Liu, C.; Li, X. Carbon storage and sequestration by urban forests in Shenyang, China. Urban For. Urban Green. 2012, 11, 121-128. [CrossRef]

2. Jo, H.K.; Kim, J.Y.; Park, H.M. Carbon reduction and Planning Strategies for Urban Parks in Seoul. Urban For. Urban Green. 2019, 41, 48-54. [CrossRef]

3. Nowak, D.J.; Greenfield, E.J.; Hoehn, R.E.; Lapoint, E. Carbon storage and Sequestration by Trees in Urban and Community Areas of the United States. Environ. Pollut. 2013, 178, 229-236. [CrossRef] [PubMed] 
4. McPherson, E.G.; Simpson, J.R. Carbon Dioxide Reduction through Urban Forestry: Guidelines for Professional and Volunteer Tree Planters; US Department of Agriculture, Forest Service, Pacific Southwest Research Station: Albany, CA, USA, 1999.

5. Gratani, L.; Varone, L.; Bonito, A. Carbon Sequestration of Four Urban Parks in Rome. Urban For. Urban Green. 2016, 19, 184-193. [CrossRef]

6. Pierdicca, R.; Paolanti, M.; Vaira, R.; Marcheggiani, E.; Malinverni, E.S.; Frontoni, E. Identifying the Use of a Park Based on Clusters of Visitors' Movements from Mobile Phone Data. J. Spat. Inf. Sci. 2019, 2019, $29-52$. [CrossRef]

7. Gulinck, H.; Marcheggiani, E.; Verhoeve, A.; Bomans, K.; Dewaelheyns, V.; Lerouge, F.; Galli, A. The Fourth Regime of Open Space. Sustainability 2018, 10, 2143. [CrossRef]

8. Sun, Y.; Xie, S.; Zhao, S. Valuing Urban Green Spaces in Mitigating Climate Change: A Citywide Estimate of Aboveground Carbon Stored in Urban Green Spaces of China's Capital. Glob. Chang. Biol. 2019, 25, 1717-1732. [CrossRef]

9. Hutyra, L.R.; Yoon, B.; Alberti, M. Terrestrial Carbon Stocks across a Gradient of Urbanization: A Study of the Seattle, WA Region. Glob. Chang. Biol. 2011, 17, 783-797. [CrossRef]

10. Chambers, D.; Périé, C.; Casajus, N.; de Blois, S. Challenges in Modelling the Abundance of 105 Tree Species in Eastern North America Using Climate, Edaphic, and Topographic Variables. For. Ecol. Manag. 2013, 291, 20-29. [CrossRef]

11. Van Ewijk, K.Y.; Randin, C.F.; Treitz, P.M.; Scott, N.A. Predicting Fine-Scale Tree Species Abundance Patterns Using Biotic Variables Derived from LiDAR and High Spatial Resolution Imagery. Remote Sens. 2014, 150, 120-131. [CrossRef]

12. Li, X.; Chen, W.Y.; Sanesi, G.; Lafortezza, R. Remote Sensing in Urban Forestry: Recent Applications and Future Directions. Remote Sens. 2019, 11, 1144. [CrossRef]

13. Myeong, S.; Nowak, D.J.; Duggin, M.J.A. Temporal Analysis of Urban Forest Carbon Storage Using Remote Sensing. Remote Sens. 2006, 101, 277-282. [CrossRef]

14. Pu, R.L. Mapping Urban Forest Tree Species Using IKONOS Imagery: Preliminary Results. Environ. Monit. Assess. 2011, 172, 199-214. [CrossRef] [PubMed]

15. Song, Y.; Imanishi, J.; Sasaki, T.; Ioki, K.; Morimoto, Y. Estimation of Broad-Leaved Canopy Growth in the Urban Forested Area Using Multi-Temporal Airborne LiDAR Datasets. Urban For. Urban Green. 2016, 16, 142-149. [CrossRef]

16. Tigges, J.; Lakes, T. High Resolution Remote Sensing for Reducing Uncertainties in Urban Forest Carbon Offset Life Cycle Assessments. Carbon Balance Manag. 2017, 12, 17. [CrossRef]

17. Chen, G.; Ozelkan, E.; Singh, K.K.; Zhou, J.; Brown, M.R.; Meentemeyer, R.K. Uncertainties in Mapping Forest Carbon in Urban Ecosystems. J. Environ. Manag. 2017, 187, 229-238. [CrossRef]

18. Singh, K.K.; Chen, G.; McCarter, J.B.; Meentemeyer, R.K. Effects of LiDAR Point Density and Landscape Context on Estimates of Urban Forest Biomass. ISPRS J. Photogramm. 2015, 101, 310-322. [CrossRef]

19. Alonzo, M.; McFadden, J.P.; Nowak, D.J.; Roberts, D.A. Mapping Urban Forest Structure and Function Using Hyperspectral Imagery and Lidar Data. Urban For. Urban Green. 2016, 17, 135-147. [CrossRef]

20. Lee, J.H.; Ko, Y.K.; McPherson, E.G. The Feasibility of Remotely Sensed Data to Estimate Urban Tree Dimensions and Biomass. Urban For. Urban Green. 2016, 16, 208-220. [CrossRef]

21. Solano, F.; Di Fazio, S.; Modica, G. A Methodology Based on GEOBIA and WorldView-3 Imagery to Derive Vegetation Indices at Tree Crown Detail in Olive Orchards. Int. J. Appl. Earth Obs. Geoinf. 2019, 83, 101912. [CrossRef]

22. Modica, G.; Solano, F.; Merlino, A.; Di Fazio, S.; Barreca, F.; Laudari, L.; Fichera, C.R. Using Landsat 8 Imagery in Detecting Cork Oak (Quercus Suber L.) Woodlands: A Case Study in Calabria (Italy). J. Agric. Eng. 2016, 47, 205-215. [CrossRef]

23. Choudhury, M.A.M.; Costanzini, S.; Despini, F.; Rossi, P.; Galli, A.; Marcheggiani, E.; Teggi, S.P.; Sensing, R. For the Identification and Characterization of Trees in Urban Areas. J. Phys. 2019, 1249. [CrossRef]

24. Pu, R.; Landry, S.A. Comparative Analysis of High Resolution IKONOS and WorldView-2 Imagery for Mapping Urban Tree Species. Remote Sens. 2012, 124, 516-533. [CrossRef]

25. Hájek, F. Object-Oriented Classification of Ikonos Satellite Data for the Identification of Tree Species Composition. J. For. Sci. 2006, 52, 181-187. [CrossRef] 
26. Ke, Y.; Quackenbush, L.J. Forest Species Classification and Tree Crown Delineation Using Quickbird Imagery. SPRS 2007, 2007, 7-11.

27. Mora, B.; Wulder, M.A.; White, J.C. Identifying Leading Species Using Tree Crown Metrics Derived from Very High Spatial Resolution Imagery in a Boreal Forest Environment. Can.J. Remote Sens. 2010, 36, 332-344. [CrossRef]

28. Sugumaran, R.; Pavuluri, M.K.; Zerr, D. The Use of High-Resolution Imagery for Identification of Urban Climax Forest Species Using Traditional and Rule-Based Classification Approach. IEEE Trans. Geosci. Remote Sens. 2003, 41, 1933-1939. [CrossRef]

29. Voss, M.; Sugumaran, R. Seasonal Effect on Tree Species Classification in an Urban Environment Using Hyperspectral Data, LiDAR, and an Object-Oriented Approach. Sensors 2008, 8, 3020-3036. [CrossRef]

30. Carleer, A.; Wolff, E. Exploitation of Very High-Resolution Satellite Data for Tree Species Identification. Photog. Eng. 2004, 70, 135-140. [CrossRef]

31. Yu, C.; Li, M.; Zhang, M. Classification of Dominant Tree Species in An Urban Forest Park Using the Remote Sensing Image of WorldView-2. In Proceedings of the 8th International Congress on Image and Signal Processing, Shenyang, China, 14-16 October 2015.

32. Katoh, M. Classifying Tree Species in a Northern Mixed Forest Using High-Resolution IKONOS Data. J. For. Resear. 2004, 9, 7-14. [CrossRef]

33. Zhang, C.; Qiu, F. Mapping Individual Tree Species in an Urban Forest Using Airborne LiDAR Data and Hyperspectral Imagery. Photogramm. Eng. Remote Sens. 2012, 78, 1079-1087. [CrossRef]

34. Kong, C.; Kai, X.; Wu, C. Classification and Extraction of Urban Land-Use Information from High-Resolution Image Based on Object Multi-Features. J. China Univ. Geoscien. 2006, 17, 151-157. [CrossRef]

35. Ikokou, G.B.; Smith, J.A. Technique for Optimal Selection of Segmentation Scale Parameters for Object-Oriented Classification of Urban Scenes. S. Afri. J. Geomat. 2013, 2, 358-369.

36. Shojanoori, R.; Shafri, H.Z.M.; Mansor, S.; Ismail, M.H. The Use of WorldView-2 Satellite Data in Urban Tree Species Mapping by Object-Based Image Analysis Technique. Sains Malays. 2016, 45, 1025-1034.

37. Adeline, K.R.M.; Briottet, X.; Paparoditis, N.; Gastellu-Etchegorry, J.P. Material Reflectance Retrieval in Urban Tree Shadows with Physics-Based Empirical Atmospheric Correction. In Proceedings of the Joint Urban Remote Sensing Event, Sao Paulo, Brazil, 21-23 April 2013.

38. Cho, M.A.; Mathieu, R.; Asner, G.P.; Naidoo, L.; Aardt, J.V.; Ramoelo, A.; Debba, P.; Wessels, K.; Main, R.; Smit, I.P.J.; et al. Mapping Tree Species Composition in South African Savannas Using an Integrated Airborne Spectral and LiDAR System. Remote Sens. 2012, 125, 214-226. [CrossRef]

39. Forzieri, G.; Tanteri, L.; Moser, G.; Catani, F.M. natural. And Urban Environments Using Airborne Multi-Sensor ADS40-MIVIS-LiDAR Synergies. Int. J. Appl. Earth Obs. 2013, 23, 313-323. [CrossRef]

40. Hao, Z.; Heng-Jia, S.; Bo-Chun, Y. Application of Hyper Spectral Remote Sensing for Urban Forestry Monitoring in Natural Disaster Zones. In Proceedings of the IEEE International Conference on Computer and Management (CAMAN), Wuhan, China, 19-21 May 2011; pp. 1-4.

41. Wania, A.; Weber, C. Hyperspectral imagery and Urban Green Observation. Urban Remote Sens. Jt. Event 2007, 1-8. [CrossRef]

42. Du, P.; Xia, J.; Zhang, W.; Tan, K.; Liu, Y.; Liu, S. Multiple Classifier System for Remote Sensing Image Classification: A Review. Sensors 2012, 12, 4764-4792. [CrossRef]

43. Gu, H.; Aditya, S.A.; Townsend, P.A. Detection of Gradients of Forest Composition in an Urban Area Using Imaging Spectroscopy. Remote Sens. 2015, 167, 168-180. [CrossRef]

44. Chen, Y.; Wen, D.; Jing, L.; Shi, P. Shadow Information Recovery in Urban Areas from Very High- Resolution Satellite Imagery. Int. J. Remote Sens. 2007, 28, 3249-3254. [CrossRef]

45. Adeline, K.R.M.; Chen, M.; Briottet, X.; Pang, S.K.; Paparoditis, N. Shadow Detection in Very High Spatial Resolution Aerial Images: A Comparative Study. ISPRS J. Photog. Remote Sens. 2013, 80, 21-38. [CrossRef]

46. Pu, R.L.; Landry, S.; Yu, Q.Y. Assessing the Potential of Multi-Seasonal High-Resolution Pleiades Satellite Imagery for Mapping Urban Tree Species. Int. J. Appl. Earth Obs. 2018, 71, 144-158. [CrossRef]

47. Li, D.; Ke, Y.; Gong, H.; Li, X. Object-Based Urban Tree Species Classification Using Bi-Temporal WorldView-2 and WorldView-3 Images. Remote Sens. 2015, 7, 16917-16937. [CrossRef]

48. Moskal, L.M.; Styers, D.M.; Halabisky, M. Monitoring Urban Tree Cover Using Object-Based Image Analysis and Public Domain Remotely Sensed Data. Remote Sens. 2011, 3, 2243-2262. [CrossRef] 
49. Li, C.; Yin, J.; Zhao, J. Extraction of Urban Vegetation from High Resolution Remote Sensing Image. In Proceedings of the International Conference on Computer Design and Applications (ICCDA), Qinhuangdao, China, 25-27 June 2010; Volume 4, pp. 403-406.

50. Lobo, A.I. segmentation. And Discriminant Analysis for the Identification of Land Cover Units in Ecology. IEEE Trans Geosci. Remote Sens. 1997, 35, 1136-1145. [CrossRef]

51. Puissant, A.; Rougier, S.; Stumpf, A. Object-Oriented Mapping of Urban Trees Using Random Forest Classifiers. Intern. J. Appl. Earth Obs. Geoinform. 2014, 26, 235-245. [CrossRef]

52. Shouse, M.; Liang, L.; Fei, S. Identification of Understory Invasive Exotic Plants with Remote Sensing in Urban Forests. Intern. J. Appl. Earth Obs. Geoinform. 2013, 21, 525-534. [CrossRef]

53. Piermattei, L.; Karel, W.; Wang, D.; Wieser, M.; Mokroš, M.; Surový, P.; Koreň, M.; Tomaštík, J.; Pfeifer, N.; Hollaus, M. Terrestrial Structure from Motion Photogrammetry for Deriving Forest Inventory Data. Remote Sens. 2019, 11, 950. [CrossRef]

54. Davies, Z.G.; Edmondson, J.L.; Heinemeyer, A.; Leake, J.R.; Gaston, K.J. Mapping an Urban Ecosystem Service: Quantifying above-Ground Carbon Storage at a City-Wide Scale. J. Appl. Ecol. 2011, 48, 1125-1134. [CrossRef]

55. Fritz, A.; Kattenborn, T.; Koch, B. UAV-Based Photogrammetric Point Clouds-Tree Stem Mapping in Open Stands in Comparison to Terrestrial Laser Scanner Point Clouds. Int. Arch. Photogramm. Remote Sens. Spat. Inf. Sci. 2013, 2013, 141-146. [CrossRef]

56. Liang, X.; Jaakkola, A.; Wang, Y.; Hyyppä, J.; Honkavaara, E.; Liu, J.; Kaartinen, H. The Use of a Hand-Held Camera for Individual Tree 3D Mapping in Forest Sample Plots. Remote Sens. 2014, 6, 6587-6603. [CrossRef]

57. Morgenroth, J.; Gomez, C. Assessment of Tree Structure Using a 3D Image Analysis Techni-A Proof of Concept. Urban For. Urban Green. 2014, 13, 198-203. [CrossRef]

58. Wróżyński, R.; Pyszny, K.; Sojka, M.; Przybyła, C.; Murat-Błażejewska, S. Ground Volume Assessment Using'Structure from Motion'photogrammetry with a Smartphone and a Compact Camera. Open Geosci. 2017, 9, 281-294. [CrossRef]

59. Miller, J.; Morgenroth, J.; Gomez, C. 3D Modelling of Individual Trees Using a Handheld Camera: Accuracy of Height, Diameter and Volume Estimates. Urban For. Urban Green. 2015, 14, 932-940. [CrossRef]

60. Peterson, E.B.M. Structure-from-Motion Photogrammetry for Three-Dimensional Structure of Lichens and Change over Time. Bryologist 2019, 122, 325-339. [CrossRef]

61. Panagiotidis, D.; Surový, P.; Kuželka, K. Accuracy of Structure from Motion Models in Comparison with Terrestrial Laser Scanner for the Analysis of DBH and Height Influence on Error Behaviour. J. For. Sci. 2016, 62, 357-365. [CrossRef]

62. De Eugenio, A.; Fernández-Landa, A.; Merino-de-Miguel, S. Modelos 3D Derivados de Fotogrametría errestre Para La Estimación de Variables de Inventario Forestal. Revsta Teledetección Asoc. Espa. Teledetección 2018, 51, 113-124. [CrossRef]

63. Tabacchi, G.; Cosmo, D.; Gasparini, L.; Gasparini, P. Aboveground tree volume and Phytomass Prediction Equations for Forest Species in Italy. Eur. J. For. Res. 2011, 130, 911-934. [CrossRef]

64. Bigi, A.; Ghermandi, G.; Harrison, R.M. Analysis of the Air Pollution Climate at a Background Site in the Po Valley. J. Environ. 2012, 14, 552-563. [CrossRef]

65. Costanzini, S.; Teggi, S.; Bigi, A.; Ghermandi, G.; Filippini, T.; Malagoli, C.; Vinceti, M. Atmospheric Dispersion Modelling and Spatial Analysis to Evaluate Population Exposure to Pesticides from Farming Processes. Atmosphere 2018, 9, 38. [CrossRef]

66. Bocchiola, D.; Nana, E.; Soncini, A. Impact of Climate Change Scenarios on Crop Yield and Water Footprint of Maize in the Po Valley of Italy. Agric. Water Manag. 2013, 116, 50-61. [CrossRef]

67. Home-GeoER. Available online: https://geoportale.regione.emilia-romagna.it/it (accessed on 3 March 2020).

68. Bossard, M.; Feranec, J.; Corine, O.J. Land Cover Technical Guide-Addendum 2000; European Environment Agency: Copenhagen, Denmark, 2000.

69. Ab Majid, I.; Latif, Z.A.; Adnan, N.A. Tree Species Classification Using Worldview-3 Data. In Proceedings of the 2016 7th IEEE Control and System Graduate Research Colloquium (ICSGRC), Shah Alam, Malaysia, 8 August 2016; pp. 73-76.

70. Inc., R.S. ENVI User Guide. 2003. Available online: https://books.google.be/books?id=WwnuAAAAMAAJ (accessed on 27 February 2020).

71. Brivio, P.; Lechi-Lechi, G.; Zilioli, E. Principi e Metodi Di Telerilevamento; CittaStudi: Milan, Italy, 2006. 
72. Ke, Y.; Quackenbush, L.J.; Im, J. Synergistic Use of QuickBird Multispectral Imagery and LIDAR Data for Object-Based Forest Species Classification. Remote Sens. Environ. 2010, 114, 1141-1154. [CrossRef]

73. Eeti, L.N.; Buddhiraju, K.M.; Bhattacharya, A. A Single Classifier Using Principal Components vs. Multi-Classifier System: In Landuse-LandCover Classification of WorldView-2 Sensor Data. ISPRS Ann. Photogramm. Remote Sens. Spat. Inf. Sci. 2014, 2, 91. [CrossRef]

74. Johnson, B.; Xie, Z. Classifying a High-Resolution Image of an Urban Area Using Super-Object Information. ISPRS J. Photogram. Remote Sens. 2013, 83, 40-49. [CrossRef]

75. Yu, Q.; Gong, P.; Clinton, N.; Biging, G.; Kelly, M.; Schirokauer, D. Object-Based Detailed Vegetation Classification with Airborne High Spatial Resolution Remote Sensing Imagery. Photogram. Engin. Remote Sens. 2006, 72, 799-811. [CrossRef]

76. Despini, F.; Teggi, S. Analysis of Temperature Maps of Water Bodies Obtained from ASTER TIR Images. Int. J. Remote Sens. 2013, 34, 3636-3653. [CrossRef]

77. Zhou, W. An Object-Based Approach for Urban Land Cover Classification: Integrating LiDAR Height and Intensity Data. IEEE Geosc. Rem. Sens. 2013, 10, 928-931. [CrossRef]

78. Youjing, Z.; Hengtong, R. Identification Scales for Urban Vegetation Classification Using High Spatial Resolution Satellite Data. IEEE Int. Geosci. Remote Sens. Symp. 2007, 1472-1475. [CrossRef]

79. Flanders, D.; Hall-Beyer, M.; Perverzoff, J. Preliminary Evaluation of ECognition Object- Based Software for Cut Block Delineation and Feature Extraction. Can. J. Remote Sens. 2003, 29, 441-452. [CrossRef]

80. Definiens AG. ECognition Version 5 Object Oriented Image Analysis User Guide; Definiens Ecognition: Munich, Germany, 2005.

81. Blanzieri, E.; Melgani, F. Nearest Neighbor Classification of Remote Sensing Images with the Maximal Margin Principle. IEEE Trans. Geosci. Remote Sens. 2008, 46, 1804-1811. [CrossRef]

82. Westoby, M.J.; Brasington, J.; Glasser, N.F.; Hambrey, M.J.; Reynolds, J.M. Structure-fromMotion'photogrammetry: A low-cost, effective tool for geoscience applications. Geomorp. Elsevier 2012, 179, 300-314. [CrossRef]

83. Castagnetti, C.; Rossi, P.; Capra, A. 3D Reconstruction of Rock Paintings: A Cost-Effective Approach Based on Modern Photogrammetry for Rapidly Mapping Archaeological Findings. IOP Conf. Ser. Mater. Sci. Eng. 2018, 364, 1. [CrossRef]

84. Goslee, K.; Walker, S.M.; Grais, A.; Murray, L.; Casarim, F.; Brown, S. Leaf Technicial Guidance Series for the Development of a Forest Carbon Monitoring System for REDD+: Module C-CS: Calculations for Estimating Carbon Stocks; Winrock International: Morrilton, AR, USA, 2010.

85. Brown, S. Estimating Biomass and Biomass Change of Tropical Forests: A Primer. Rome FAO For. Pap. 1986, Volume 134. Available online: https://www.mendeley.com/catalogue/b1fb0fc8-a2673060-81bf-8aecd572c4e8/?utm_source=desktop\&utm_medium=1.19.4\&utm_campaign=open_catalog\& userDocumentId=\%7Bb468e77d-c2aa-48fc-aed0-029115bde0e8\%7D (accessed on 27 February 2020).

86. Losi, C.J.; Siccama, T.G.; Condit, R.; Morales, J.E. Analysis of Alternative Methods for Estimating Carbon Stock in Young Tropical Plantatiions. For. Ecol. Manag. 2003, 184, 355-368. [CrossRef]

87. Vashum, K.T.; Jayakumar, S. Methods to Estimate Above-Ground Biomass and Carbon Stock in Natural Forests-a Review. J. Ecosyst. Ecography 2012, 2, 1-7. [CrossRef]

88. Whittaker, R.H.; Likens, G.E. Carbon in the Biota. In Carbon in the Biosphere, Proceedings of the 24th Brookhaven Symposium in Biology, Upton, NY, USA, 16-18 May 1973; Woodwell, G.M., Pecan, E.V., Eds.; United States Atomic Energy Commission: Washington, DC, USA, 1973; pp. 281-302.

89. Marklund, L.G.; Schoene, D.I. Global Assessment of Growing Stock, Biomass and Carbon Stock. Forest Resources Assessment Programme Working Paper 106. 2006. Available online: http://www.fao.org/3/aah849e.pdf (accessed on 25 February 2020).

90. Vicharnakorn, P.; Shrestha, R.P.; Nagai, M.; Salam, A.P.; Kiratiprayoon, S. Carbon Stock Assessment Using Remote Sensing and Forest Inventory Data in Savannakhet, Lao PDR. Remote Sens. 2014, 6, 5452-5479. [CrossRef]

91. Panel, I. On Climate Change (IPCC); Cambridge University Press: Cambridge, UK, 2007.

92. Kanniah, K.D.; Muhamad, N.; Kang, C.S. Remote Sensing Assessment of Carbon Storage by Urban Forest. IOP Conf. Ser. Earth Environ. Sci. 2014, 18, 1. [CrossRef] 
93. Rahetlah, B.V.; Salgado, P.; Andrianarisoa, B.; Tillard, E.; Razafindrazaka, H.; Le Mezo, L.; Ramalanjaona, V.L. Relationship between Normalized Difference Vegetation Index (NDVI) and Forage Biomass Yield in the Vakinankaratra Region; Livestock Research for Rural Development, Cirad - Agritrop: Madagascar, East Africa, 2014; p. 11.

94. Goswami, S.; Gamon, J.; Vargas, S.; Tweedie, C. Relationships of NDVI, Biomass, and Leaf Area Index (LAI) for Six Key Plant Species in Barrow, Alaska. PeerJ Prepr. 2015, 19. [CrossRef]

95. Coelho, A.P.; Rosalen, D.L.; Faria, R.T. Vegetation Indices in the Prediction of Biomass and Grain Yield of White Oat under Irrigation Levels. Pesqui. Agropecuária Trop. 2018, 48, 109-117. [CrossRef]

96. Jung, M. LecoS-A QGIS Plugin for Automated Landscape Ecology Analysis; University of Copenhagen: Copenhagen, Denmark, 2013.

97. Gupta, D.L.; Malviya, A.K.; Singh, S. Performance Analysis of Classification Tree Learning Algorithms. Int. J. Comput. Appl. 2012, 1, 55.

98. Immitzer, M.; Vuolo, F.; Atzberger, C. First Experience with Sentinel-2 Data for Crop and Tree Species Classifications in Central Europe. Remote Sens. 2016, 8, 3. [CrossRef]

99. So-In, C.; Mongkonchai, N.; Aimtongkham, P.; Wijitsopon, K.; Rujirakul, K. An Evaluation of Data Mining Classification Models for Network Intrusion Detection. In Proceedings of the 2014 Fourth International Conference on Digital Information and Communication Technology and Its Applications (DICTAP), Bangkok, Thailand, 6-8 May 2014; IEEE: Piscataway, NJ, USA, 2014; pp. 90-94.

100. Foody, G. Assessing the Accuracy of Remotely Sensed Data: Principles and Practices. Photogramm. Rec. 2010, 25, 204-205. [CrossRef]

101. Helldén, U. A Test of Landsat-2 Imagery and Digital Data for Thematic Mapping: Illustrated by an Environmental Study in Northern Kenya, Lund University. Nat. Geogr. Inst. Report No. 47. 1980. Available online: https://www.semanticscholar.org/paper/A-test-of-landsat-2-imagery-and-digital-data-forby-Helld\%C3\%A9n/d7f84b92a8198b293719960a2a33791f7b632326 (accessed on 25 February 2020).

102. Matikainen, L.; Karila, K. Segment-Based Land Cover Mapping of a Suburban Area-Comparison of High-Resolution Remotely Sensed Datasets Using Classification Trees and Test Field Points. Remote Sens. 2011, 3, 1777-1804. [CrossRef]

103. Cohen, J. Weighted Kappa: Nominal Scale Agreement Provision for Scaled Disagreement or Partial Credit. Psychol. Bull. 1968, 70, 213. [CrossRef]

104. Banko, G. A Review of Assessing the Accuracy of Classifications of Remotely Sensed Data and of Methods Including Remote Sensing Data in Forest Inventory; International Institute for Applied Systems Analysis: Laxenburg, Austria, 1998.

105. San-Miguel-Ayanz, J.; de Rigo, D.; Caudullo, G.; Houston, D.T. (Eds.) European Atlas of Forest Tree Species; Publication Office of the European Union: Luxembourg, 2016.

106. De Rigo, D.; Enescu, C.M.; Houston, D.T.; Caudullo, G. Populus Nigra in Europe: Distribution, Habitat, Usage and Threats. In European Atlas of Forest Tree Species; San-Miguel-Ayanz, J., de Rigo, D., Caudullo, G., Houston Durrant, T., Mauri, A., Eds.; Publication Office of the European Union: Luxembourg, 2016; p. e0182a4.

107. Eaton, E.; Caudullo, G.; Oliveira, S.; de Rigo, D. Quercus robur and Quercus Petraea in Europe: Distribution, Habitat, Usage and Threats. In European Atlas of Forest Tree Species; San-Miguel-Ayanz, J., de Rigo, D., Caudullo, G., Houston Durrant, T., Mauri, A., Eds.; Publication Office of the European Union: Luxembourg, 2016; p. e01c6df.

108. Zecchin, B.; Caudullo, G.; de Rigo, D. Acer Campestre in Europe: Distribution, Habitat, Usage and Threats. In European Atlas of Forest Tree Species; San-Miguel-Ayanz, J., de Rigo, D., Caudullo, G., Houston Durrant, T., Mauri, A., Eds.; Publication Office of the European Union: Luxembourg, 2016; p. e012c65.

109. Balboa-Murias, M.A.; Rojo, A.; Álvarez, J.G.; Merino, A. Carbon and Nutrient Stocks in Mature Quercus Robur L. Stands in NW Spain Annals of Forest Science. Ann. For. Sci. 2006, 63, 557-565. [CrossRef]

110. Hjelm, B.; Mola-Yudego, B.; Dimitriou, I.; Johansson, T. Diameter-Height Models for Fast-Growing Poplar Plantations on Agricultural Land in Sweden. BioEnergy Res. 2015, 8, 1759-1768. [CrossRef]

111. Russo, A.; Escobedo, F.J.; Timilsina, N.; Schmitt, A.O.; Varela, S.; Zerbe, S. Assessing Urban Tree Carbon Storage and Sequestration in Bolzano, Italy. Int. J. Biodivers. Sci. Ecosyst. Serv. Manag. 2014, 10, 54-70. [CrossRef]

112. Trees and Shrubs Hardy in the British Isles. Vol. IV. Ri-Z. Available online: https://www.cabdirect.org/ cabdirect/abstract/19800666681 (accessed on 4 May 2020). 
113. Laliberte, A.S.; Koppa, J.; Fredrickson, E.L.; Rango, A. Comparison of nearest neighbor and rule-based decision tree classification in an object-oriented environment. Proceedings of IEEE international Geoscience and Remote Sensing Symposium, Denver, CO, USA, 31 July 2006; pp. 3923-3926. [CrossRef]

114. Zheng, G.; Moskal, L.M. Retrieving Leaf Area Index (LAI) Using Remote Sensing: Theories, Methods and Sensors. Sensors 2009, 9, 2719-2745. [CrossRef]

115. Franklin, S.E.; Hall, R.J.; Moskal, L.M.; Maudie, A.J.; Lavigne, M.B. Incorporating Texture into Classification of Forest Species Composition from Airborne Multispectral Images. Int. J. Remote Sens. 2000, 21, 61-79. [CrossRef]

116. Sequestered Standing Carbon Stock in Selective Tree Species Grown in University Campus at Aurangabad, Maharashtra, India. Available online: https://www.researchgate.net/publication/50315368_Sequestered_ standing_carbon_stock_in_selective_tree_species_grown_in_University_campus_at_Aurangabad_ Maharashtra_India (accessed on 21 August 2020).

117. Green Structure and Urban Planning-Final Report. Available online: https://www.cost.eu/publications/ green-structure-and-urban-planning-final-report/ (accessed on 17 August 2020).

118. Sturiale, L.; Scuderi, A. The Role of Green Infrastructures in Urban Planning for Climate Change Adaptation. Climate 2019, 7, 119. [CrossRef]

Publisher's Note: MDPI stays neutral with regard to jurisdictional claims in published maps and institutional affiliations.

(C) 2020 by the authors. Licensee MDPI, Basel, Switzerland. This article is an open access article distributed under the terms and conditions of the Creative Commons Attribution (CC BY) license (http://creativecommons.org/licenses/by/4.0/). 